\title{
SOME OBSERVATIONS ON THE ACTIVITY OF THREE ANTISEPTICS USED AS BLADDER IRRIGANTS IN THE TREATMENT OF URINARY TRACT INFECTION IN PATIENTS WITH INDWELLING CATHETERS
}

\author{
By ${ }^{1}$ D. J. Stickler, B.Sc., M.A., D.Phil., ${ }^{1}$ S. Plant, ${ }^{2}$ N. H. Bunni, M.B., Ch.B., D.T.C.D. \\ and ${ }^{2}$ J. C. Chawla, M.B., B.S., F.R.C.S., M.D., A.M. \\ ${ }^{1}$ Department of Applied Biology, University of Wales; Institute of Science and Technology, \\ Cardiff, Wales. \\ 2 Spinal Injury Unit, Rookwood Hospital, Cardiff.
}

\begin{abstract}
A comparison has been made of the activity of three antiseptics that are used as bladder irrigants in the treatment of urinary tract infection in catheterised patients. At the concentrations and exposure times used for bladder irrigation, phenoxyethanol $(2.4 \% \mathrm{v} / \mathrm{v})$ proved to be highly bactericidal against urine-grown cells of all the common urinary pathogens tested. Chlorhexidine $(200 \mu \mathrm{g} / \mathrm{ml})$ was active against Escherichia coli and produced significant reductions in the viability of Klebsiella pneumoniae, Proteus mirabilis and Pseudomonas aeruginosa but failed to eradicate Providencia stuartii. Exposure to noxythiolin $(2.5 \% \mathrm{v} / \mathrm{v})$ for $20 \mathrm{~min}$ had little effect on any of the bacteria, even though all strains tested had been recorded as noxythiolin-sensitive by conventional plate sensitivity tests. Contact with noxythiolin for periods of at least I-2 hrs was necessary before extensive bactericidal activity was detected. These results provide an explanation of the poor clinical performance of noxythiolin that we have observed.
\end{abstract}

Key words: Urinary tract infection; Bladder irrigation; Indwelling catheter; Antiseptics.

\section{Introduction}

IRRIGATION of the bladder with an antiseptic solution has been advocated as a method of controlling urinary tract infections in catheterised patients (Guttman, 1973; Lowbury et al., 1975; Tyrrell et al., 1979). Amongst the antibacterial compounds that have been recommended for this purpose is noxythiolin (McFadyen, 1967). The work reported in this paper was prompted by observations made during the use of this agent to treat urinary infections in two patients with indwelling catheters. The organisms present in the urines were Providencia stuartii and Klebsiella pneumoniae. Both had been reported by the laboratory as multi-drug-resistant but noxythiolin-sensitive. Examination of the daily urine samples taken after irrigation, however, showed no reduction in the numbers of viable bacteria in the urine and at the end of the Io-day treatment period the organisms persisted at greater than $10^{5}$ bacteria $/ \mathrm{ml}$. These findings led us to an in vitro study in which the activity of noxythiolin against urine-grown Gramnegative bacteria was compared with that of two other antiseptics that have been recommended as bladder irrigants, chlorhexidine (Paterson et al., 1960) and phenoxyethanol (Guttmann, I973).

\section{Methods and Materials}

The irrigation procedure used in the spinal injury unit involves the introduction of 50 to $100 \mathrm{ml}$ of the antiseptic into the bladder by injection through the 
catheter. The precise volume instilled is dependent on the capacity of the bladder. The antibacterial solution is allowed to bathe the bladder for 20 minutes before normal drainage is restored. In our in vitro studies to determine the bactericidal activity of the bladder irrigants, we have attempted to set up experimental conditions which relate to these clinical circumstances. Thus, assuming that the residual volume of urine in the catheterised bladder is $20 \mathrm{ml}$, we challenged I-ml samples of urine-grown cells with $5 \mathrm{ml}$ of antiseptic and determined the numbers of bacteria surviving after incubation for 20 minutes at $37^{\circ}$.

The urine used as the growth medium was a pooled sample which had been sterilised by membrane filtration. The bacteria used were $E$. coli NCTC Io4I8, and clinical strains of Providencia stuartii, Pseudomonas aeruginosa, Proteus mirabilis and Klebsiella pneumoniae that had been isolated from urinary tract infections in patients at the spinal injury unit.

Mixed cultures were used in the experiments because urine from chronic infections in catheterised patients often contain a mixed population of bacterial species (Garrod et al., I973). In addition, the intention was to test the suggestion that the application of an antiseptic to such mixed bacterial communities may lead to the selection of one organism in preference to another (Stickler and Thomas, I980). Three series of mixtures were set up each containing the lactose-fermenting (LF) species $E$. coli together with one of the non-lactose-fermenting (NLF) species Pv. stuartii, Pr. mirabilis and Ps. aeruginosa. A similar series was also produced each containing $K$. pneumoniae as the lactose-fermenting species. The bacteria were grown as pure cultures in urine at $37^{\circ}$ for 6 hours and then mixed immediately prior to each experiment.

The viable bacterial cell counts on these mixtures were performed on CLED agar (Oxoid Ltd) as this permitted the distinction of the component organisms as blue (NLF) or yellow (LF) colonies.

Noxythiolin (Noxyflex) was obtained from Geistlich Ltd., chlorhexidine from ICI Ltd. and phenoxyethanol from Nippa Laboratories Ltd.

\section{Results}

The results of challenging triplicate samples of each of the mixed bacterial communities with the three antiseptics are shown in Tables I-III. Control cultures in which $5 \mathrm{ml}$ of sterile distilled water was added to the urine-grown cells, showed no significant reduction in viable cell counts during the 20-minute period. The data in Table I indicate that noxythiolin $(2.5 \% \mathrm{w} / \mathrm{v})$ is particularly ineffective in reducing the numbers of viable bacteria of all five species. Experiments were subsequently set up to establish whether increasing the time of exposure to noxythiolin would improve the bactericidal activity. The results of these experiments are shown in Table IV and they indicate that incubation with noxythiolin for periods greater than an hour are required in order to eliminate $E$. coli, Pv. stuartii and Pr. mirabilis from urine.

The work reported in Tables I-IV was carried out in samples of urine that had been collected from healthy individuals, pooled and membrane-filtered. The urine was thus free of pus cells, red blood cells and other organic debris that is often present in the urine of the catheterised patient. To test the activity of the three antiseptics in the presence of such materials, samples of urine were collected from patients having mixed urinary infections with significant pyuria and these were challenged with the antiseptics for 20 minutes at $37^{\circ}$. The results of these experiments are shown in Table V. 


\section{TABLE I}

The bactericidal activity of noxythiolin against mixed cultures of urine-grown organisms

\begin{tabular}{|c|c|c|c|c|}
\hline $\begin{array}{l}\text { Reaction } \\
\text { Mixture }\end{array}$ & \multicolumn{2}{|c|}{$\begin{array}{l}\text { No. of viable cells } / \mathrm{ml} \text { of each } \\
\text { species originally present in the } \\
\text { urine/antiseptic mixture }\end{array}$} & \multicolumn{2}{|c|}{$\begin{array}{l}\text { No. of viable cells } / \mathrm{ml} \text { surviving } \\
\text { after I ml of urine was added to } \\
5 \mathrm{ml} \text { of noxythiolin }(2 \cdot 5 \% \mathrm{w} / \mathrm{v}) \& \\
\text { incubated at } 37^{\circ} \text { for } 20 \text { minutes }\end{array}$} \\
\hline I. $\begin{array}{l}\mathrm{a} \\
\mathrm{b} \\
\mathrm{c}\end{array}$ & $\begin{array}{l}\text { E. coli } \\
7 \cdot 3 \times 10^{6} \\
8 \cdot 0 \times 10^{6} \\
2 \cdot 2 \times 10^{7}\end{array}$ & $\begin{array}{l}\text { Ps. aeruginosa } \\
3 \cdot 7 \times 10^{8} \\
2 \cdot 7 \times 10^{7} \\
5 \cdot 1 \times 10^{6}\end{array}$ & $\begin{array}{l}\text { E. coli } \\
4.9 \times 10^{6} \\
6.4 \times 10^{6} \\
3.4 \times 10^{7}\end{array}$ & $\begin{array}{l}\text { Ps. aeruginosa } \\
7 \cdot 9 \times 10^{6} \\
6 \cdot 2 \times 10^{6} \\
4 \cdot 3 \times 10^{6}\end{array}$ \\
\hline 2. $\begin{array}{l}\mathrm{a} \\
\mathrm{b} \\
\mathrm{c}\end{array}$ & $\begin{array}{l}\text { E. coli } \\
\mathrm{I} \cdot \mathrm{I} \times 1 \mathrm{IO}^{7} \\
9 \cdot 3 \times 10^{6} \\
\mathrm{I} \cdot 0 \times 10^{7}\end{array}$ & $\begin{array}{l}\text { P. mirabilis } \\
\mathrm{I} \cdot 5 \times 10^{7} \\
2 \cdot 0 \times 10^{7} \\
\mathrm{I} \cdot 7 \times 10^{7}\end{array}$ & $\begin{array}{l}\text { E. coli } \\
2 \cdot 9 \times 10^{4} \\
2 \cdot 0 \times 10^{7} \\
3 \cdot 3 \times 10^{6}\end{array}$ & $\begin{array}{l}\text { P. mirabilis } \\
6 \cdot 4 \times 10^{6} \\
\mathrm{I} \cdot 9 \times 10^{7} \\
\mathrm{I} \cdot 9 \times 10^{7}\end{array}$ \\
\hline 3. $\begin{array}{l}\mathrm{a} \\
\mathrm{b} \\
\mathrm{c}\end{array}$ & $\begin{array}{l}\text { E. coli } \\
6 \cdot 7 \times 10^{6} \\
8 \cdot 2 \times 10^{6} \\
2 \cdot 0 \times 10^{7}\end{array}$ & $\begin{array}{l}\text { Pv. stuartii } \\
2 \cdot \mathrm{I} \times 1 \mathrm{I}^{7} \\
\mathrm{I} \cdot 7 \times 10^{7} \\
\mathrm{I} \cdot \mathrm{I} \times \mathrm{IO}^{7}\end{array}$ & $\begin{array}{l}\text { E. coli } \\
2 \cdot 4 \times 10^{6} \\
2 \cdot 5 \times 10^{4} \\
6 \cdot 0 \times 10^{6}\end{array}$ & $\begin{array}{l}\text { Pv. stuartii } \\
\mathrm{I} \cdot 2 \times 10^{7} \\
8 \cdot 6 \times 10^{4} \\
\mathrm{I} \cdot 4 \times 10^{7}\end{array}$ \\
\hline 4. $\begin{array}{l}\mathrm{a} \\
\mathrm{b} \\
\mathrm{c}\end{array}$ & $\begin{array}{c}\text { K. pneumoniae } \\
1 \cdot 8 \times 10^{7} \\
2 \cdot 3 \times 10^{7} \\
9 \cdot 0 \times 10^{6}\end{array}$ & $\begin{array}{c}\text { Ps. aeruginosa } \\
\mathrm{I} \cdot 7 \times 10^{7} \\
2 \cdot 8 \times 10^{7} \\
6 \cdot 0 \times 10^{6}\end{array}$ & $\begin{array}{c}K . \text { pneumoniae } \\
7 \cdot 8 \times 10^{6} \\
\mathrm{I} \cdot \mathrm{I} \times \mathrm{IO}^{7} \\
\mathrm{I} \cdot \mathrm{I} \times \mathrm{IO}^{7}\end{array}$ & $\begin{array}{l}\text { Ps. aeruginosa } \\
3.5 \times 10^{6} \\
1 \cdot 0 \times 10^{6} \\
5 \cdot 0 \times 10^{6}\end{array}$ \\
\hline 5. $\begin{array}{l}\mathrm{a} \\
\mathrm{b} \\
\mathrm{c}\end{array}$ & $\begin{array}{c}\text { K. pneumoniae } \\
2 \cdot 7 \times 10^{7} \\
1 \cdot 6 \times 10^{7} \\
I \cdot 1 \times 10^{7}\end{array}$ & $\begin{array}{l}\text { P. mirabilis } \\
8 \cdot 9 \times 10^{7} \\
\mathrm{I} \cdot 8 \times 10^{7} \\
\mathrm{I} \cdot 4 \times 10^{7}\end{array}$ & $\begin{array}{c}\text { K. pneumoniae } \\
3.5 \times 10^{4} \\
2.4 \times 10^{4} \\
2.5 \times 10^{7}\end{array}$ & $\begin{array}{c}\text { P. mirabilis } \\
6 \cdot 5 \times 10^{4} \\
2 \cdot 4 \times 10^{5} \\
1 \cdot 1 \times 10^{7}\end{array}$ \\
\hline 6. $\begin{array}{l}\mathrm{a} \\
\mathrm{b} \\
\mathrm{c}\end{array}$ & $\begin{array}{c}K . \text { pneumoniae } \\
\mathrm{I} \cdot 4 \times 10^{7} \\
9 \cdot 6 \times 10^{6} \\
1 \cdot 0 \times 10^{7}\end{array}$ & $\begin{array}{c}\text { Pv. stuartii } \\
2 \cdot 3 \times 10^{7} \\
\mathrm{I} \cdot 3 \times 10^{9} \\
\mathrm{I} \cdot 8 \times 10^{7}\end{array}$ & $\begin{array}{c}\text { K. pneumoniae } \\
6 \cdot 8 \times \mathrm{IO}^{5} \\
9 \cdot 9 \times 1 \mathrm{I}^{6} \\
\mathrm{I} \cdot 0 \times 10^{7}\end{array}$ & $\begin{array}{c}\text { Pv. stuartii } \\
2 \cdot 0 \times 10^{6} \\
\mathrm{I} \cdot 6 \times 10^{7} \\
\mathrm{I} \cdot 0 \times 10^{7}\end{array}$ \\
\hline
\end{tabular}

A retrospective examination was then carried out of the records of the 22 patients who had undergone noxythiolin bladder washouts during the preceding I2 months. In addition to the two cases referred to in the introduction, failure to eliminate infections with organisms that had been reported as noxythiolin-sensitive by conventional laboratory procedures, was recorded in a further 16 patients.

\section{Discussion}

The results presented in Table I demonstrate that exposure to noxythiolin $(2.5 \% \mathrm{w} / \mathrm{v})$ for 20 minutes at $37^{\circ}$ does not have a significant bactericidal effect on urine-grown cells of the common urinary pathogens. The data clearly provide an explanation for the poor clinical performance of the antiseptic that we have observed. Geistlich \& Sons Ltd. recommend that for treating urinary tract 


\section{TABLE II}

The bactericidal activity of chlorhexidine against mixed cultures of urine-grown organisms

\begin{tabular}{|c|c|c|c|c|}
\hline $\begin{array}{l}\text { Reaction } \\
\text { Mixture }\end{array}$ & \multicolumn{2}{|c|}{$\begin{array}{l}\text { No. of viable cells } / \mathrm{ml} \text { of each } \\
\text { species originally present in the } \\
\text { urine/antiseptic mixture }\end{array}$} & \multicolumn{2}{|c|}{$\begin{array}{l}\text { No. of viable cells } / \mathrm{ml} \text { surviving } \\
\text { after I ml of urine was added to } \\
5 \mathrm{ml} \text { of chlorhexidine }(200 \\
\mu \mathrm{g} / \mathrm{ml}) \& \text { incubated at } 37^{\circ} \text { for } \\
20 \text { minutes. }\end{array}$} \\
\hline I. $\begin{array}{l}\mathrm{a} \\
\mathrm{b} \\
\mathrm{c}\end{array}$ & $\begin{array}{l}\text { E. coli } \\
2.5 \times 10^{6} \\
\mathrm{I} \cdot 5 \times 10^{7} \\
7 \cdot 9 \times 10^{6}\end{array}$ & $\begin{array}{l}\text { Ps. aeruginosa } \\
5 \cdot 0 \times 10^{7} \\
4.5 \times 10^{7} \\
2 \cdot 0 \times 10^{6}\end{array}$ & $\begin{array}{l}\text { E. coli } \\
\text { N.D.* } \\
\text { N.D. } \\
\text { N.D. }\end{array}$ & $\begin{array}{l}\text { Ps. aeruginosa } \\
5 \cdot 3 \times \mathrm{IO}^{2} \\
\text { N.D. } \\
\text { N.D. }\end{array}$ \\
\hline $\begin{array}{l}\text { 2. } \begin{array}{l}\mathrm{a} \\
\mathrm{b} \\
\mathrm{c}\end{array}\end{array}$ & $\begin{array}{l}\text { E. coli } \\
\mathrm{I} \cdot 0 \times 10^{7} \\
3 \cdot 6 \times 10^{6} \\
2 \cdot 1 \times 10^{7}\end{array}$ & $\begin{array}{l}\text { P. mirabilis } \\
2 \cdot 4 \times 10^{6} \\
6 \cdot 7 \times 10^{6} \\
1 \cdot 2 \times 10^{7}\end{array}$ & $\begin{array}{l}\text { E. coli } \\
\text { N.D. } \\
\text { N.D. } \\
\text { N.D. }\end{array}$ & $\begin{array}{l}\text { P. mirabilis } \\
\text { N.D. } \\
\text { N.D. } \\
3.8 \times \mathrm{IO}^{3}\end{array}$ \\
\hline 3. $\begin{array}{l}\mathrm{a} \\
\mathrm{b} \\
\mathrm{c}\end{array}$ & $\begin{array}{l}E . \text { coli } \\
\mathrm{I} \cdot 3 \times 10^{6} \\
\mathrm{I} \cdot 2 \times 10^{7} \\
8 \cdot 1 \times 10^{6}\end{array}$ & $\begin{array}{l}\text { Pv. stuartii } \\
7 \cdot 5 \times 10^{5} \\
5 \cdot 9 \times 10^{7} \\
5 \cdot 1 \times 10^{7}\end{array}$ & $\begin{array}{l}\text { E. coli } \\
\text { N.D. } \\
\text { N.D. } \\
\text { N.D. }\end{array}$ & $\begin{array}{l}\text { Pv. stuartii } \\
7 \cdot 0 \times 10^{5} \\
5 \cdot 6 \times 10^{5} \\
9 \cdot 1 \times 10^{5}\end{array}$ \\
\hline 4. $\begin{array}{l}\mathrm{a} \\
\mathrm{b} \\
\mathrm{c}\end{array}$ & $\begin{array}{c}\text { K. pneumoniae } \\
1 \cdot 3 \times 10^{7} \\
1 \cdot 9 \times 10^{7} \\
3 \cdot 0 \times 10^{7}\end{array}$ & $\begin{array}{l}\text { Ps. aeruginosa } \\
3 \cdot 3 \times 10^{7} \\
8 \cdot 5 \times 10^{6} \\
1 \cdot 6 \times 10^{7}\end{array}$ & $\begin{array}{l}\text { K. pneumoniae } \\
\text { N.D. } \\
\text { N.D. } \\
6.7 \times 10^{3}\end{array}$ & $\begin{array}{l}\text { Ps. aeruginosa } \\
\text { N.D. } \\
\text { N.D. } \\
8 \cdot 0 \times \mathrm{IO}^{3}\end{array}$ \\
\hline 5. $\begin{array}{l}\mathrm{a} \\
\mathrm{b} \\
\mathrm{c}\end{array}$ & $\begin{array}{c}\text { K. pneumoniae } \\
1 \cdot 3 \times 10^{7} \\
I \cdot 5 \times 10^{7} \\
I \cdot 0 \times 10^{7}\end{array}$ & $\begin{array}{l}\text { P. mirabilis } \\
6 \cdot 6 \times 10^{5} \\
1 \cdot 3 \times 10^{6} \\
8 \cdot 8 \times 10^{5}\end{array}$ & $\begin{array}{c}\text { K. pneumoniae } \\
\mathrm{I} \cdot 9 \times \mathrm{IO}^{3} \\
3 \cdot 4 \times \mathrm{IO}^{3} \\
7 \cdot 0 \times \mathrm{IO}^{2}\end{array}$ & $\begin{array}{l}\text { P. mirabilis } \\
\text { N.D. } \\
\text { N.D. } \\
\text { N.D. }\end{array}$ \\
\hline 6. $\begin{array}{l}\mathrm{a} \\
\mathrm{b} \\
\mathrm{c}\end{array}$ & $\begin{array}{c}K . \text { pneumoniae } \\
\mathrm{I} \cdot 9 \times 10^{7} \\
\mathrm{I} \cdot \mathrm{I} \times 10^{7} \\
\mathrm{I} \cdot 5 \times 10^{7}\end{array}$ & $\begin{array}{c}\text { Pv. stuartii } \\
3.4 \times 10^{7} \\
5.6 \times 10^{6} \\
\mathrm{I} \cdot 3 \times 10^{7}\end{array}$ & $\begin{array}{c}\text { K. pneumoniae } \\
\text { N.D. } \\
\text { N.D. } \\
\text { N.D. }\end{array}$ & $\begin{array}{c}\text { Pv. stuartii } \\
8 \cdot 0 \times 10^{5} \\
\mathrm{I} \cdot 6 \times 10^{5} \\
\mathrm{I} \cdot 7 \times 10^{6}\end{array}$ \\
\hline
\end{tabular}

* N.D. indicates that no survivors were detected.

infections, $100 \mathrm{ml}$ of $2.5 \% \mathrm{w} / \mathrm{v}$ noxythiolin should be instilled once or twice daily and drained off after 30 minutes to I hour. The experiments reported in Table IV suggest that the time of exposure to the antiseptic should be up to 2 hours. Simple single instillations for this length of time are of course impractical. Spine-injured patients, often with contracted bladders and on high fluid intakes, experience considerable discomfort if the instillation time is greater than 20-30 minutes.

While noxythiolin is certainly a compound with activity against a wide range of organisms, many of the reports on its activity have only measured its ability to inhibit the growth of bacteria after overnight incubation on agar plates (Brodhage \& Stofer, I96I ; Haler, 1963). Horsefield (1967) reported that concentrations of noxythiolin which inhibited the growth of strains of Proteus on blood agar plates 


\section{TABLE III}

The bactericidal activity of phenoxyethanol against mixed cultures of urine-grown organisms

\begin{tabular}{|c|c|c|c|c|}
\hline $\begin{array}{l}\text { Reaction } \\
\text { Mixture }\end{array}$ & \multicolumn{2}{|c|}{$\begin{array}{l}\text { No. of viable cells } / \mathrm{ml} \text { of each } \\
\text { species originally present in the } \\
\text { urine/antiseptic mixture }\end{array}$} & \multicolumn{2}{|c|}{$\begin{array}{l}\text { No. of viable cells } / \mathrm{ml} \text { surviving } \\
\text { after I ml of urine was added to } \\
5 \mathrm{ml} \text { of phenoxyethanol }(2 \cdot 4 \% \\
\mathrm{v} / \mathrm{y}) \& \text { incubated at } 37^{\circ} \text { for } 20 \\
\text { minutes }\end{array}$} \\
\hline I. $\begin{array}{l}\mathrm{a} \\
\mathrm{b} \\
\mathrm{c}\end{array}$ & $\begin{array}{l}\text { E. coli } \\
6 \cdot 7 \times 10^{6} \\
6 \cdot 8 \times 10^{6} \\
\mathrm{I} \cdot 2 \times 10^{7}\end{array}$ & $\begin{array}{l}\text { Ps. aeruginosa } \\
2 \cdot 0 \times 10^{6} \\
2 \cdot 9 \times 10^{6} \\
2 \cdot 5 \times 10^{6}\end{array}$ & $\begin{array}{l}\text { E. coli } \\
\text { N.D. } \\
\text { N.D. } \\
\text { N.D. }\end{array}$ & $\begin{array}{l}\text { Ps. aeruginosa } \\
\text { N.D. } \\
\text { N.D. } \\
\text { N.D. }\end{array}$ \\
\hline 2. $\begin{array}{l}\mathrm{a} \\
\mathrm{b} \\
\mathrm{c}\end{array}$ & $\begin{array}{l}\text { E. coli } \\
7 \cdot 3 \times 10^{6} \\
2 \cdot 5 \times 10^{7} \\
6 \cdot 5 \times 10^{6}\end{array}$ & $\begin{array}{l}\text { P. mirabilis } \\
\mathrm{I} \cdot 9 \times 10^{7} \\
3 \cdot 3 \times 10^{7} \\
1 \cdot 6 \times 10^{7}\end{array}$ & $\begin{array}{l}\text { E. coli } \\
\text { N.D. } \\
\text { N.D. } \\
\text { N.D. }\end{array}$ & $\begin{array}{l}\text { P. mirabilis } \\
\text { N.D. } \\
\text { N.D. } \\
\text { N.D. }\end{array}$ \\
\hline 3. $\begin{array}{l}\mathrm{a} \\
\mathrm{b} \\
\mathrm{c}\end{array}$ & $\begin{array}{l}\text { E. coli } \\
\mathrm{I} \cdot 0 \times 10^{7} \\
3.6 \times 10^{7} \\
6 \cdot 0 \times 10^{6}\end{array}$ & $\begin{array}{l}\text { Pv. stuartii } \\
\mathrm{I} \cdot 2 \times 10^{7} \\
2 \cdot 0 \times 10^{7} \\
7 \cdot 3 \times 10^{6}\end{array}$ & $\begin{array}{l}\text { E. coli } \\
\text { N.D. } \\
\text { N.D. } \\
\text { N.D. }\end{array}$ & $\begin{array}{l}\text { Pv. stuartii } \\
\text { N.D. } \\
\text { N.D. } \\
\text { N.D. }\end{array}$ \\
\hline 4. $\begin{array}{l}\mathrm{a} \\
\mathrm{b} \\
\mathrm{c}\end{array}$ & $\begin{array}{c}\text { K. pneumoniae } \\
\mathrm{I} \cdot \mathrm{I} \times 1 \mathrm{I}^{7} \\
9 \cdot 3 \times 10^{6} \\
6 \cdot 2 \times 10^{6}\end{array}$ & $\begin{array}{l}\text { Ps. aeruginosa } \\
7 \cdot 3 \times 10^{6} \\
4 \cdot 0 \times 10^{6} \\
2 \cdot 2 \times 10^{6}\end{array}$ & $\begin{array}{l}\text { K. pneumoniae } \\
\text { N.D. } \\
\text { N.D. } \\
\text { N.D. }\end{array}$ & $\begin{array}{l}\text { Ps. aeruginosa } \\
\text { M.D. } \\
\text { N.D. } \\
\text { N.D. }\end{array}$ \\
\hline 5. $\begin{array}{l}\mathrm{a} \\
\mathrm{b} \\
\mathrm{c}\end{array}$ & $\begin{array}{c}\text { K. pneumoniae } \\
4.9 \times 10^{6} \\
2 \cdot 0 \times 10^{7} \\
8 \cdot 6 \times 10^{6}\end{array}$ & $\begin{array}{l}\text { P. mirabilis } \\
\mathrm{I} \cdot 2 \times 10^{7} \\
3 \cdot 4 \times 10^{7} \\
\mathrm{I} \cdot 2 \times 10^{7}\end{array}$ & $\begin{array}{l}\text { K. pneumoniae } \\
\text { N.D. } \\
\text { N.D. } \\
\text { N.D. }\end{array}$ & $\begin{array}{l}\text { P. mirabilis } \\
\text { N D. } \\
\text { N.D. } \\
\text { N.D. }\end{array}$ \\
\hline 6. $\begin{array}{l}\mathrm{a} \\
\mathrm{b} \\
\mathrm{c}\end{array}$ & $\begin{array}{c}\text { K. pneumoniae } \\
\mathrm{I} \cdot 2 \times 10^{7} \\
\mathrm{I} \cdot \mathrm{I} \times 1 \mathrm{IO}^{7} \\
8 \cdot 7 \times 10^{6}\end{array}$ & $\begin{array}{c}\text { Pv. startuii } \\
9 \cdot 3 \times 10^{6} \\
\mathrm{I} \cdot \mathrm{I} \times 10^{7} \\
8 \cdot 4 \times 10^{6}\end{array}$ & $\begin{array}{c}\text { K. pneumoniae } \\
\text { N.D. } \\
\text { N.D. } \\
\text { N.D. }\end{array}$ & $\begin{array}{l}\text { Pv. stuartii } \\
\text { N.D. } \\
\text { N.D. } \\
\text { N.D. }\end{array}$ \\
\hline
\end{tabular}

\section{TABLE IV}

The effect of exposure time on the survival of urine-grown cells challenged with noxythiolin

\begin{tabular}{|c|c|c|c|c|}
\hline \multirow[t]{2}{*}{$\begin{array}{c}\text { Exposure } \\
\text { Time } \\
\text { (minutes) }\end{array}$} & \multicolumn{4}{|c|}{$\begin{array}{l}\text { Number of viable bacterial cells } / \mathrm{ml} \text { present in the incubation mixtures } \\
\text { after I ml of urine had been added to } 5 \mathrm{ml} \text { of noxythiolin }(2.5 \% \mathrm{w} / \mathrm{v}) \text { and } \\
\text { incubated at } 37^{\circ}\end{array}$} \\
\hline & \multicolumn{2}{|c|}{ Mixture $\mathrm{A}$} & \multicolumn{2}{|c|}{ Mixture B } \\
\hline 0 & $\begin{array}{l}\text { E. coli } \\
2.0 \times 10^{7}\end{array}$ & $\begin{array}{l}\text { Pv. stuartii } \\
\mathrm{I} \cdot \mathrm{I} \times \mathrm{IO}^{7}\end{array}$ & $\begin{array}{l}\text { E. coli } \\
\mathrm{I} \cdot \mathrm{O} \times \mathrm{IO}^{7}\end{array}$ & $\begin{array}{l}\text { P. mirabilis } \\
\mathrm{I} \cdot 7 \times \mathrm{IO}^{7}\end{array}$ \\
\hline 20 & $6.0 \times 10^{6}$ & $\mathrm{I} \cdot 4 \times 10^{7}$ & $3.3 \times 10^{6}$ & $\mathrm{I} \cdot 9 \times 10^{7}$ \\
\hline 60 & $5.4 \times 10^{4}$ & $\mathrm{I} \cdot 5 \times 10^{7}$ & $8.0 \times 10^{1}$ & $1 \cdot 6 \times 10^{6}$ \\
\hline 120 & N.D. & N.D. & N.D. & N.D. \\
\hline
\end{tabular}


were not bactericidal against these organisms after 6 hours incubation in broth. Bactericidal activity against $E$. coli, Streptococcus faecalis, $K$. aerogenes, Pr. mirabilis and Ps. aeruginosa was demonstrated by Williams, Hamilton-Miller and Brumfitt (I976) after 30 hours exposure to I per cent $\mathrm{w} / \mathrm{v}$ solutions at $37^{\circ}$. Chattopadhyay (I977) showed that incubation times from I to 4 hours with noxythiolin $(2 \cdot 4$ per cent $\mathrm{w} / \mathrm{v}$ ) were required to sterilize suspensions of $P$ s. aeruginosa ( $\mathrm{IO}^{5} \mathrm{cells} / \mathrm{ml}$ ), and when the inoculum size was increased to $10^{6} \mathrm{cells} / \mathrm{ml}$, some strains survived for 18 hours in the 2.5 per cent $\mathrm{w} / \mathrm{v}$ concentration of the antiseptic. In these later two studies the organisms were exposed to noxythiolin in dilute aqueous suspension. In the bladder irrigation procedure the antiseptic is required to be bactericidal in the presence of urine, leucocytes and other cellular and organic debris, all materials that can reduce the activity of antiseptics. The activity of noxythiolin is due to its decomposition in solution to produce formaldehyde. Kingston (1965) reported that in urine the complete decomposition of noxythiolin yielded only I5 per cent of the formaldehyde produced in aqueous solutions and he concluded that the constituents of urine reduced the amount of free formaldehyde. In addition, at the mean $p \mathrm{H}$ of urine $(6 \cdot 25)$ noxythiolin evolved formaldehyde at a slow rate. In view of all these observations it is not surprising that populations of organisms growing in the bladder urine of catheterised patients are not dramatically reduced on short-term exposure to noxythiolin. In this context it is interesting that Sutherland (1967) in his original studies on the use of noxythiolin to treat chronic urinary tract infections reported that instillations of $100 \mathrm{ml}$ of a 2.5 per cent $\mathrm{w} / \mathrm{v}$ solution three times daily, gave poor results and recommended that a 24-hour continuous irrigation with a I per cent $\mathrm{w} / \mathrm{v}$ solution should be used.

All the organisms used in this study were reported as noxythiolin-sensitive from the standard filter-paper disc sensitivity-testing procedure. The data in Table I highlight the dangers of extrapolating from the results of a laboratory test which measures the ability of an agent to inhibit the growth of bacteria on a nutrient agar plate over an I8-hour period, to a clinical situation where the agent is required to be bactericidal in urine within 20 minutes.

In contrast to the failure of noxythiolin, the other two agents exhibited marked antibacterial activity. No survivors were recorded from any of the cultures challenged with phenoxyethanol (Table III). Chlorhexidine eliminated $E$. coli from all the mixed populations and generally produced significant reductions in the viability of K. pneumoniae, Pr. mirabilis, and Ps. aeruginosa but failed to deal with Pv. stuartii. Reaction mixtures 3. a, b and c (Table II), for example indicate that the application of chlorhexidine to a mixed urinary infection composed of $E$. coli and $P v$. stuartii, could well leave the Pv. stuartii free to multiply in the post-irrigation urine. This would be an unfortunate development, the antiseptic policy having led to the selection of a notoriously drug-resistant species (Li and Miller, I970, Overturf et al., I974).

Guttmann (I973) recommended that phenoxyethanol should be used for bladder irrigation when Ps. aeruginosa was prevalent. Our observations support this view and suggest that the recommendation should be extended to include Pv. stuartii.

The conditions of our test procedure are not an exact model of the irrigated bladder. The residual urine is often greater than $20 \mathrm{ml}$ and generally it is not possible to introduce more than $50 \mathrm{ml}$ of the antiseptic. In practice therefore, the urine-grown cells in the bladder are frequently exposed to lower concentrations of the agents than those used in our tests. Another factor is that urine continues to flow into the bladder during the irrigation and in the spine-injured patients 
on high fluid intakes this provides a considerable additional dilution of the antiseptic.

The rationale for the treatment regime with bladder irrigants seems to us to be far from soundly based. A study using a physical model of the bladder such as that of Greenwood and O'Grady (I975) might lead to some useful information on the frequency and duration of irrigation most likely to be effective in dealing with infections in the catheterised bladder.

\section{RÉSUMÉ}

On a fait une comparaison de l'activité de trois antiseptiques employés pour irriguer la vessie dans le traitement d'infection urinaire parmi des malades cathétérisés. Aux concentrations et aux temps d'exposition employés pour l'irrigation de la vessie, phenoxyethanol $(2 \cdot 4 \% \mathrm{v} / \mathrm{v})$ s'est montré extrêmement bactéricide contre les cellules, qu'on a cultivées de l'urine, de tous les microbes pathogènes urinaires éprouvés. Chlorhexidine $(200 \mu \mathrm{g} / \mathrm{ml})$ était actif contre Escherichia coli et a produit des réductions significatives dans la viabilité de Klebsiella pneumoniae, Proteus mirabilis et Psuedomonas aeruginosa mais a manqué de faire disparaître Providencia stuartii. L'exposition à noxythiolin $(2.5 \% \mathrm{w} / \mathrm{v})$ pour 20 minutes n'a produit que peu d'effet sur aucune des bactéries même si tous les genres éprouvés étaient enregistrés comme sensitifs à noxythiolin quand on avait employé des épreuves de sensitivité normales (sur une cuvette). Le contact avec noxythiolin pendant des périodes d'au moins entre I-2 heures était nécessaire avant que l'activité considérable bactéricide fût découverte. Ces résultats fournissent une explication pour le pauvre fonctionnement clinique de noxythiolin que nous avons observé.

\section{ZUSAMMENFASSUNG}

Es wurde ein Vergleich in der Aktivität von drei verschiedenen Antiseptika gemacht, welche zur Blasenspühlung bei der Behandlung von Harwegsinfektionen an katheterisierten Patienten gebraucht wurden.

In Konzentration und Zeit der Wirkung gebraucht für die Blasenspühlung, Phenoxyethanol $(2 \cdot 4 \% \mathrm{v} / \mathrm{v})$ bewies die Hoechste bakterientötende Wirkung gegenüber Zellen produziert vom Urin, von denen bisher üblich getesteten Urinpatogenen.

Chlorhexidine $(200 \mu \mathrm{g} / \mathrm{ml})$ zeigte Aktivität gegen Escherichia coli und entwickelte bedeutende Reduktion in der Überlebung von Klebsiella pneumoniae, Proteus mirabilis und Pseudomonas aeruginosa, fehlte aber bei der Ausrottung von Providencia stuartii.

Die Wirkungszeit von $20 \mathrm{~min}$. bei Noxythiolin $(2.5 \% \mathrm{w} / \mathrm{v})$, zeigte eine sehr kleine bakterientötende Wirkung, obschon die Abkunft aller Baketerien getestet und festgehalten wurde; als eine Noxythiolin Empfindlichkeit beim Kurzzeit-Empfindlichkeitstest.

Ein Kontakt mit Noxythiolin von mindestens I-2 Stunden war nötig um eine ausgedehnte bakterientötende Wirkung zu erziehlen. Diese Resultate versehen eine Erklärung für die geringe Leistung von Noxythiolin, welche wir beobachten konnten.

\section{REFERENCES}

Brodhage, E. and Stofer, A. R. (I96I). Polyoxymethyleneurea, a new type of locally applicable chemotherapeutic agent. Antiobiotics and Chemotherapy, II, 205-206.

ChatTopadhyay, B. (I977). Noxythiolin resistant organisms in a district general hospital. British Medical fournal, 2, I I 2 I-I I 22.

Garrod, L. P., Lambert, H. P. and O'Grady, F. (1973). Antibiotic and Chemotherapy. 4th edition. Edinburgh: Churchill Livingstone.

GREENWOOD, D. and O'GRADY, F. (I975). Response of ampicillin-resistant Escherichia coli to cephalosporins in an in vitro model simulating conditions of bacterial growth in the urinary bladder. British f. exp. Path., 56, 167-171.

Guttman, L. (1973). Spinal Cord Injuries. Comprehensive management and research. Oxford. Blackwells.

Haler, D. (1963). Polynoxylin. Nature, 198, 400-401.

HORSEFIELD, D. (1967). In vitro studies on the action of noxythiolin on antibiotic-resistant Gram-negative bacteria. Clinical Trials fournal, 4, 625-627. 
Kingston, D. (I965). Release of formaldehyde from polynoxylin and noxythiolin. $\mathcal{F}$. Clinical Pathology, 18, 666-667.

LI, K., MILleR, C. (I970). Pathogenic bacteria and their sensitivity patterns in a hospital population of geriatric patients with chronic disease. F. Am. Geriat. Soc., 18, 286-294.

Lowbury, E. J. L., Ayliffe, G. A. J., Geddes, A. M., and Williams, J. D. (I975). Control of Hospital Infection: a Practical Handbook. Chapman and Hall, London.

MCFADYEN, I. R. (1967). Comparison of noxythiolin (Noxyflex) and chlorhexidine (Hibitane) instillation after intermittent catheterization. Clinical Trials fournal, 4, 654-658.

Overturf, G. D., Wilkins, J., and Ressler, R. (I974). Emergence of resistance of Providencia stuartii to multiple antibiotics: speciation and biochemical characterisation of Providencia. F. Infectious Diseases, 129, 353-357.

PATERSON, M. L., BARR, W., MACDonald, S. (I960). Urinary infection after colporrhaphy: its incidence, causation and prevention. F. Obstet. Gynaec., 67, 394-40I.

STICKLER, D. J. and Thomas, B. (I980). Antiseptic and antibiotic resistance in Gramnegative bacteria causing urinary tract infection. Fournal of Clinical Pathology, 33, 288-296.

SutherLAND, J. W., (1967). Noxythiolin (Noxyflex) instillations in chronic urinary infections. Clinical Trials fournal, 4, 649-653.

Tyrrell, D. A. J., Phillips, I., Goodwin, C. S., and Blowers, R. (I979). Microbial Disease: the use of the laboratory in diagnosis, therapy and control. Edward Arnold: London.

Williams, R. J., Hamilton-Miller, J. M. T. and Brumfitt, W. (I976). Microbiological studies on some bladder irrigation fluids. Infection, 4, 31-34. 